\title{
3.С. Бочарова
}

\section{ПРАВОВОЕ ПОЛОЖЕНИЕ РУССКИХ БЕЖЕНЦЕВ ВО ФРАНЦИИ В 1920-1930-е ГОАЫ}

Аннотация. В статье рассматривается процесс адаптации национального законодательства Франции по отночению к иностранным гражданам, в частности к русским изгнанникам. К бывщим подданным Российской империи нельзя было применить законы прежнего государства, а также законы Советской России, так как они не являлись ее гражданами. На формирование франиузского законодательства и административной практики оказали влияние признание Францией Советского Союза в 1924 ., ратификация международных актов - Согламения (1928), а затем Конвенции (1933) о правовом положении русских и армянских беженцев. $К$ кониу 1920-х годов эмигранты, чтобы уравняться в правах с местным населением, стремились к натурализации.

Ключевые слова: русские беженцы, Ф.Нансен, В.А. Маклаков, русское зарубежье.

Бочарова Зоя Сергеевна - доктор исторических наук,

профессор кафедры ЮНЕСКО по изучению глобальных проблем

Московского государственного университета имени М.В. Ломоносова.

E-mail: zsbotcharova@mail.ru

Z.S. Bocharova. The Legal Status of Russian Refugees in France in the 1920-1930-ies

Abstract. The article studies the process of adapting national laws of France to foreign citizens and to Russian exiles in particular. It was not possible to apply the laws of the former state and the laws of the Soviet Russia to the former subjects of the Russian Empire, as they were not its citizens. France had formed its legal system and the administrative practice after the recognition of the Soviet Union in 1924 and the ratification of international acts - the Treaty (1928) and then the Convention (1933) on the legal status of Russian and Armenian refugees. By the end of 1920-ies the emigrants sought naturalization to receive equal rights with local population.

Keywords: Russian refugees, F. Nansen, V.A. Maklakov, the Russian Émigré. 
Bocharova Zoja Sergeevna - Doctor of Historical sciences,
Professor of the UNESCO Department on Global problems
of Lomonosov Moscow State University. E-mail: zsbotcharova@mail.ru

Франция является одной из самых гостеприимных стран, у нее давние миграционные традиции. Конституция Франции, написанная во время Великой французской революции в 1793 г., хотя и не была применена, предоставляла убежище иностранцам, борющимся «за дело свободы» и вынужденных покинуть свое государство. Становление же соответствующего национального законодательства происходило уже в XX в. и шло параллельно с формированием правовой базы для решения проблем беженцев на межгосударственном уровне. Речь шла прежде всего об урегулировании положения тех лиц, которые остались без попечения правительства государства своего происхождения.

Для русских изгнанников, ушедших в эмиграцию после революционных потрясений 1917 г. и Гражданской войны, Франция стала своеобразным виртуальным политическим центром трансграничной Зарубежной России, сформировавшейся в 1920-1930-е годы. Французское правительство сыграло не последнюю роль в ликвидации правового вакуума, в котором оказались россияне, не признавшие советскую власть. Уникальность их положения заключалась в прецеденте - за ними не стояло государство, которое защищало бы их интересы: Российская империя перестала существовать (а право умирает вместе с государством), а принимать помощь и защиту от созданной на ее развалинах Советской России (позже - Советского Союза) изгнанники не желали. Русская пореволюционная эмиграция стала катализатором разработки международных норм относительно правового режима беженцев.

Началась борьба за признание мировым сообществом особого статуса лиц, оказавшихся без защиты своего отечества. Нельзя сказать, что состояние бесподданства (apolid) было неизвестно международному праву. Оно считалось недопустимым (и сегодня считается), поскольку установилась практика равноправности подданных и иностранцев. Во многих государствах (Франция, Италия, Бельгия, Голландия, Швейцария и др.) личный статут иностранца (его личная дееспособность, семейное и наследственное право) определялся в международной сфере его национальным законом, а не местожительством (domicil). Бесподданные, «эти международные бродяги» (Лоран), с одной стороны, могли пользоваться правами, а с другой - были свободны от обязанностей, налагаемых на граждан государств, оставаясь в привилегированном положении [20, с. 127-130]. Но массовость, значимость, авторитет лидеров зарубежья, отсутствие «национального права» заставили мировое сообщество иначе посмотреть на проблему. Благодаря усилиям российской эмиграции, верховного комиссара по делам беженцев Лиги Наций и доброй 
воле правительств к началу 1930-х годов сформировались принципиальные положения международных правовых норм, регулировавших статус беженцев. На этом опыте основывается и современная юридическая практика.

По инициативе французской секции в Лиге Наций был составлен проект об учреждении Верховного комиссариата по делам русских беженцев для координации усилий государств. Франция одной из первых ратифицировала международные акты об особом юридическом статусе русских эмигрантов Соглашение от 30 июня 1928 г. и Женевскую конвенцию от 28 октября 1933 г. о юридическом статусе русских и армянских беженцев. И не только потому, что играла активную роль на мировой арене, но и в силу наличия многочисленной русской эмиграции в стране. По оценке В.Ф. Зеелера, выпустившего в 1937 г. справочник «Русские во Франции», их число составило почти 100 тыс. человек [15, с. 3].

Следует выделить три этапа урегулирования положения русской эмиграции: 1) до признания СССР Францией, т.е. до 1925 г. (формально 28 октября 1924 г.) с вехой - 1 января 1923 г., когда были введены нансеновские паспорта [подробнее см.: 3, с. 74-116]; 2) 1925-1930 гг.; 3) с 1930 по 1939 г. Первые два периода стали временем формирования правовых основ взаимоотношений беженцев и власти. Третий начинается после ратифицированного французским правительством 11 января 1930 г. постановления о правовом положении русских и армянских беженцев в связи с межправительственным соглашением, принятым 30 июня 1928 г.

Урегулирование правового положения русских предполагало деятельность по ряду направлений. Следовало создать соответствующие учреждения, в ведении которых находилась бы эта категория иностранцев; определить, какому правовому режиму, т.е. каким законам, надлежало им подчиняться; выработать документы для проживания в стране; условия реализации права передвижения по Франции, а также въезда - выезда; возможности трудоустройства.

В 20-30-е годы Российское дипломатическое представительство играло важную посредническую роль между эмиграцией и французским правительством. Налаживание отношений Франции с СССР встревожило русских изгнанников. В.А. Маклаков, посол Временного правительства, не успевший вручить верительные грамоты, вступил в переговоры с французскими торговопромышленными кругами, деятелями парламентского комитета. Затем 28 марта 1924 г. в российском посольстве обсуждался вопрос о создании специального органа для защиты интересов русской колонии на случай возможного признания Францией советского правительства и последующем упразднении существующего посольства $[14$, с. 243]. Следовало продумать, как обезопасить частные и полугосударственные российские учреждения во Франции от захвата их советской стороной, какому законодательству будут 
подлежать эмигранты. В результате из представителей русских общественных организаций в июле 1924 г. был создан Эмигрантский комитет [8, с. 2325]. 21 октября того же года эмигрантская газета «Последние новости» опубликовала заявление В.А. Маклакова о судьбе русских беженцев во Франции, в котором он подчеркивал, что в связи с ожидающимся признанием Францией СССР «для известного числа беженцев будет благом, если им обеспечат получение французского гражданства». Риск остаться «массой без отечества» для огромного большинства тех, кто бежал от советской власти, был вызван угрозой ликвидации легального представительства. В.А. Маклаков настаивал на временном сохранении посольства, консульств для того, «чтобы сделать возможным существование наших соотечественников за границей», обеспечив им правовую защиту. Представители русских общественных организаций, собравшиеся под его председательством, выработали меморандум о положении русских беженцев во Франции и вручили его французскому правительству. Эмигрантскому комитету пришлось упорно бороться с их бесправием и добиваться для них не только права на жительство, но и права на труд, и не в порядке единичных разрешений в том или ином случае, а в введении единых законных норм, регулировавших жизнь русских во Франции.

После признания Францией Советского Союза 28 октября 1924 г. вместо российского посольства и консульств были учреждены офисы по делам русских беженцев. Центральный офис возглавлял В.А. Маклаков. При нем была учреждена должность представителя верховного комиссара по делам русских беженцев Ф. Нансена, на которую был назначен М. Пан [8, с. 18]. Общественной поддержкой В.А. Маклакову стал Эмигрантский комитет. Деятельность как центрального, так и местных офисов (в Париже, Марселе, Ницце и Лионе) регламентировалась циркуляром МИДа от 9 мая 1925 г., направленным префектам, и декретом президента Франции от 11 января 1930 г. Офисы признавались правительством учреждениями, исполнявшими обязанности консульств по делам русских беженцев [16, с. 197]. Во внутренней жизни офисы продолжали руководствоваться указаниями В.А. Маклакова.

Самые серьезные меры по урегулированию статуса русских беженцев предпринимались во Франции после вступления в законную силу межправительственного Соглашения «О правовом положении русских и армянских беженцев» 1928 г., т.е. с 1 февраля 1930 г. В.Ф. Зеелер следующим образом оценил ратификацию 11 января 1930 г. французским правительством этого Соглашения: «Так долго, в течение многих лет, ждавший своего признания статут русских беженцев, наконец, принят, прошел через законодательные учреждения, утвержден Президентом и распубликован в законном порядке стал законом. Нельзя сказать, что этим сполна и в благоприятном смысле разрешен весь беженский вопрос, что лучшего желать нельзя: еще многое 164 
в правовом положении эмигранта русского остается и неясным, и неудовлетворительным, но статус настолько расширил и, главное, уяснил и уточнил наше положение во Франции, что признание его надлежит считать явлением несомненно значительным, и важным, и положительным» [15, с. 9].

В соответствии с принятым Соглашением 1928 г. русские беженцы уравнивались в правах с французскими гражданами на предоставление им преимуществ, которые имеют иностранцы на условиях взаимности, гарантировалось соблюдение принципа невысылки. Пункт 7 Соглашения рекомендовал относиться к высылаемым благожелательно, считаться с невозможностью скорого выезда. Также предусматривалось узаконение института представителя верховного комиссара Ф. Нансена, который наделялся консульскими правами и назначался с согласия министра иностранных дел Франции. Но это не повлекло за собой изменений в деятельности беженских офисов. Они продолжали выдавать документы. Лишь в тех случаях, когда закон предъявлял особо повышенные требования, на выданных в офисах официальных бумагах ставилась подпись и печать представителя Ф. Нансена [10; 4, с. 18-19].

Легально въехавший во Францию россиянин пользовался равными с другими иностранцами правами, беспрепятственно получал удостоверение личности (карт д'идантите), если желал остановиться в стране на срок более двух месяцев. Удостоверение было обязательно для всех лиц старше 15 лет и давало право на повсеместное жительство и свободу передвижения в пределах Франции и ее колоний, поступление на работу, пользование французскими лечебными учреждениями. Для проживания в стране русские старые дореволюционные паспорта, выданные российскими миссиями, не имели никакого значения.

Беженцы получали карт д’идантите на основании национального паспорта. Для ее получения русским чинам, служившим во французской армии (в частности в составе русского экспедиционного корпуса, отправленного русским царем в 1916-1917 гг. на французский и македонский фронты, насчитывалось 750 офицеров и 45 тыс. нижних чинов), достаточно было свидетельства, а в иностранном легионе - увольнительного [11, с. 135].

Заявление о карт д’идантите подавалось на специальном бланке, выдаваемом бесплатно в префектуре. В нем эмигрант указывал, в том числе, фамилию и адреса двух французских граждан, которые, в случае надобности, могли дать справку о просителе. К прошению прилагались паспорт, с которым иностранец прибыл во Францию (с визой французского консула), 4 фото, удостоверение о месте жительства (сертифика де домисиль), заверенное комиссаром полиции, и сбор за карт д’идантите. По поводу этого свидетельства Дон-Аминадо, известный своими афоризмами, сочинил двустишие: «Приспособьте декольте к вашим карт д’идантите!» [18, с. 89]. 
Свидетельство о личности было трех видов. Первое (carte sans profession) выдавалось лицам: а) не имевшим права работать или служить, б) служащим, зарабатывающим 18 тыс. фр. в год и более 160 фр. в день, в) занятыми свободными профессиями, не состоявшим ни на какой службе. Второе выдавалось: а) студентам или учащимся учебных заведений, не профессионального характера (список учебных заведений имелся в префектуре), б) журналистам и писателям, состоявшим в союзах иностранной прессы, или в соответствующих синдикатах, в) ученым, г) служащим и рабочим, прибывшим во Францию по контрактам, или получившим разрешение на работу от Министерства труда или его административных учреждений (в провинции). Третья разновидность карты - бесплатная - предназначалась для участников Первой мировой войны, состоявших в рядах французских полков или иностранного легиона.

Стоимость этих свидетельств о личности, продолжительность их действия варьировались. У Саши Черного читаем в одной из сатирических заметок за 1925 г.: «Вопрос о карт-д’идантите разрешен, наконец, декретом Президента республики окончательно: писатели при обмене платят 10 франков» [17]. Видимо, в 1926 г. плата резко возросла. Для лиц, не имевших постоянной работы, она была весьма обременительной. На 1930 г. удостоверения первого вида приобретались за 100 франков, льготные, второго вида, - за 20. В 1935 г. была опубликована информация о том, что карт д’идантите, выдаваемая на три года, будет стоить 160 франков вместо 220. Такса за льготную карт д'идантите (студентам, писателям, журналистам и др.) оставалась без перемен - 35 франков.

Политическим эмигрантам карт д’идантите выдавалась на пять лет и возобновлялась автоматически. Отобрана могла быть только в случае высылки, на основании судебного решения. Кроме постоянной карт д'идантите существовала ограниченная, выдававшаяся на срок, указанный в визе (обычно шесть месяцев) [16, с. 76-80].

Процедура получения карт д'идантите отнимала немало времени у эмигрантов. Так, Н.В. Кодрянская в своей книге об А.М. Ремизове приводит такой эпизод. А.М. Ремизову нужно было возобновить в префектуре этот документ (он жил в Париже на рю Буало, № 7). В то время в префектуре приходилось выстаивать в очереди часами, иногда по два дня. Когда Алексей Михайлович собрался пойти, было очень холодно, и он оделся не совсем обычно: поверх пальто закутался в длинную красную женскую шаль, перевязав ее на груди крест-накрест, как это делают бабы. На голову надел еще вывезенную из России странной формы высокую суконную шапку, опушенную мехом. Странно одетый, сгорбленный, маленький, в очках, с лохматыми, торчащими вверх бровями, в невероятно больших калошах, зашагал в префектуру. С прошением, расписанным им самим и разукрашенным разными заставками и закорючками, 166 
он без задержки прошел в здание. При виде такого необычайного посетителя ряды очереди разомкнулись. Чиновники, конечно, тоже сразу обратили внимание на него и на его прошение, один подозвал его вне очереди. Ремизов потом, посмеиваясь, рассказывал: «Чиновник оказался большим любителем каллиграфии и пришел в восторг от моего прошения». Оно обошло всю префектуру, и его автор получил свое удостоверение без проволочки, что обычно так легко не делалось [9, с. 15-16]. Те, кто видел автографы А.М. Ремизова, поймут, о чем идет речь.

1 января 1923 г. во Франции были введены нансеновские паспорта («сертификат д'идантите»). Не все русские эмигранты приняли их, ибо получение такого паспорта означало признание без гражданства: той России, юридическую связь с которой подтверждал старый национальный паспорт, уже не существовало, а советский паспорт они не хотели иметь. С 1930 г., после ратификации Соглашения о юридическом положении русских и армянских беженцев 1928 г., нансеновские паспорта выдавались только беженцам, покинувшим Россию до 28 октября 1924 г., т.е. до даты признания Францией советского правительства. Эти паспорта могли получить лица старше 15 лет в префектуре того департамента, где эмигрант проживал, на основании национального паспорта и карт д'идантите. Нансеновские паспорта заменяли заграничные, а до их введения, т.е. до 1923 г., визы проставлялись в национальные паспорта.

В справочнике «Русские во Франции» указывалось, что лица, въехавшие в страну в 20-30-е годы с советским паспортом, но не возобновлявшие его в течение пяти лет, могли также ходатайствовать о выдаче нансеновского паспорта в МВД Франции для облегчения выезда за границу [15, с. 9-25]. Однако с 1930 г. в Эмигрантский комитет стали обращаться бывшие советские граждане с просьбами о помощи, так как французское правительство прекратило выдавать нансеновские паспорта этой категории иностранцев после ратификации Соглашения 1928 г. Оно не отказывалось считать обладателей советских паспортов политическими эмигрантами (рефюжье), давать им привилегии эмигрантов, право убежища, не выдавать их по требованию советских властей и т.д. Но предоставление нансеновского паспорта означало бы признание их лицами без гражданства, т.е. апатридами. У бывших советских граждан оставался обычный путь - натурализация.

Нансеновские паспорта призваны были главным образом обеспечить беженцам доступ в те государства, в которых находились советские дипломатические представительства, и где, соответственно, старые паспорта, свидетельствовавшие о юридической связи с прежней государственностью, не признавались. Для пребывания в стране нансеновский паспорт был необязателен. Если визировались прежние паспорта, требовалась предварительная виза 
старых российских консульских учреждений. Они же покровительствовали и нансенистам.

Во Франции (так же, как и в Италии, Бельгии, Голландии, Швейцарии и других странах) личный статус иностранца (его личная дееспособность, семейное и наследственное право) обычно определялся его национальным законом, а не местожительством (domicil). До признания CCCP французские суды игнорировали действие декрета ВЦИК от 15 декабря 1921 г. о лишении гражданства некоторых категорий лиц, находившихся за границей, и рассматривали эмигрантов как российских граждан, подчиненных дореволюционному праву. Об этом говорил на съезде русских юристов в Берлине 3 октября 1922 г. присяжный поверенный П. Дубинский. Во Франции российские события рассматривались как еще не законченный революционный процесс. Более того, французская судебная практика исходила из признания фактического отсутствия правосудия в России. П. Дубинский высказался за «симбиоз» советского законодательства, положений X тома Свода законов Российской империи и практики французских судов [см.: Руль. Берлин, 1922. 4 октября].

28 апреля 1925 г. Министерство юстиции разослало циркуляр «О законодательстве, подлежащем применению в отношении русских во Франции» прокурорам судебных палат по вопросу о юридическом статусе русских во Франции. В отношении актов и законов, совершенных до 28 октября 1924 г. (дата признания СССР Францией) циркуляр предоставлял судам определять их юридическое значение на основании русского закона, при действии коего они были совершены [21]. Относительно деяний, произошедших после признания СССР, к русским эмигрантам применялось французское право как закон их нового места жительства (domicil).

Так, лица, вступавшие в брак во Франции, регистрировали его в мэрии. Церковный брак мог быть заключен только после гражданского и был необязателен. Для заключения брака в мэрию следовало представить карт д'идантите, сертификат де домисиль (свидетельство на право жительства), метрические выписки о рождении. Церковный развод, произведенный за границей в государствах, где таковой был действителен, являлся действительным также и во Франции. В делах о разводах французские суды применяли положения, представляющие собой комбинацию русских дореволюционных законов с французскими. Вопрос о поводах для разводов решался по старым русским законам, сам развод совершался по французским законам [7, с. 65].

Единообразие судебной практики по делам русских беженцев установилось после принятия Соглашения 30 июня 1928 г. Рекомендации Лиги Наций были согласованы с основными законами Французской Республики. Работа кодификационного характера была проведена во французских отдельных министерствах. Изменений в законодательном порядке, т.е. приспособления 168 
законодательства к новым требованиям, потребовали вопросы о правоспособности русских эмигрантов, вступивших в брак за границей, и об освобождении русских на суде от залога, который обычно платили иностранцы. При этом вполне оправданно звучало заявление Министерства внутренних дел о том, что среди русских необходимо различать, с одной стороны, беженцев, c другой - граждан СССР. Наиболее пристального внимания требовали вопросы, решавшиеся в административном порядке, а не в суде: о труде, высылках, визах, признании за беженцами преимуществ, обусловленных началами взаимности, и т.д.

Преступность в беженской среде была низкая, но даже условно осужденные иностранцы должны были покинуть страну. Для того чтобы выехать из страны, требовалась виза. Европейские страны давали визы крайне неохотно. Возникала тупиковая ситуация. Французские власти чуть ли не контрабандой провозили нарушителей закона через свою границу, но таким же порядком переправляли их назад. Так, русского рабочего с фабрики Рено, получившего условно двухмесячный срок за драку в баре, депортировали к ближайшей границе - с Бельгией, здесь его арестовали за нелегальный переход и выслали обратно. Во Франции его задерживали за неисполнение приговора суда и вновь депортировали - и так без конца. В Россию русский не мог быть выслан. Зачастую беженцы подвергались высылке без особых на то причин [6, с. 130]. Оказавшись в безвыходном положении, когда подчас даже на устройство дел не давалось время, высылаемому приходилось искать защиты не только Эмигрантского комитета, но и Лиги защиты прав человека и гражданина.

21 ноября 1934 г. Союз русских адвокатов во Франции обратился к министру юстиции с письмом по поводу высылки русских из Франции. Российские юристы обратили внимание министра на несоответствие, которое существовало между законом 1849 г., предусматривавшим высылку иностранцев, и наличием группы иностранцев без отечества. В письме, в частности, говорилось: «Неподчинение русских беженцев распоряжению о высылке не есть акт неповиновения или нарушения закона, а невозможность, фактическая и юридическая, перейти границу соседнего государства без визы. Несмотря на наличие непреодолимой силы, суды выносят обвинительные приговоры, считаясь с вопросом формально и не входя в обсуждение мотивов неисполнения административного распоряжения» [12]. Поскольку готовился закон об ужесточении наказания за неподчинение распоряжению о высылке, Союз русских адвокатов при поддержке французского политического деятеля сенатора Г. Готро просил содействия в применении пункта 7 декрета президента от 17 января 1930 г., рекомендовавшего не прибегать к высылке русских беженцев, и Конвенции 1933 г. 
В октябре 1935 г. были введены новые нормы наказания для иностранцев, не подчинившихся приказу о высылке. Прежде высылка и наказание за неподчинение нормировались законом от 3 декабря 1849 г., согласно которому «всякий иностранец, высланный из Франции и возвратившийся на ее территорию без разрешения правительства, предается суду и подлежит заключению в тюрьме сроком от 1 до 6 месяцев». Рост числа иностранцев во Франции, международное экономическое и политическое положение, простота передвижения и т.д. затрудняли административный контроль. В результате последовало увеличение срока наказания - от шести месяцев до двух лет. Но и здесь для русских беженцев были сделаны исключения. Условия применения этого закона по отношению к апатридам специально оговаривались инструкцией министра внутренних дел, чем писали «Последние новости» 3 ноября 1935 г.

Главным вопросом для эмигрантов оставалось получение средств к существованию. Им предлагалась работа, как правило, в копях, в сельском хозяйстве. Даже если русские находили другую работу, отказываясь от тяжелой, то Бюро труда не давало разрешения на нее. Если все же устраивались на работу в отраслях, где среди французов была безработица, Бюро труда оказывало давление на хозяина, чтобы русского заменили французом [ГА РФ. Ф. 5853. Оп. 1. Д. 19. Л. 551]. Начиная с декабря 1925 г. прекратилось поступление контрактов на работы во Францию в местное отделение МБТ в Константинополе [19]. Со второй половины 1929 г. уменьшился приток во Францию фабрично-заводских рабочих, выписываемых по контракту из Эстонии, Польши, Болгарии и других стран, испытывавших экономический кризис.

К массовой безработице, которая коснулась, в первую очередь, иностранцев, привели технические нововведения, в частности «американизация» автомобильных заводов. Переход к звуковому кино повлек за собой отказ от статистов. Развитие электрических граммофонов и радио вытеснило механическую музыку из кафе и синема. Все это сужало возможности трудоустройства для беженцев. На попечении благотворительных организаций, ранее оказывавших помощь только детям, инвалидам, старикам, нетрудоспособным, оказывались молодые и физически здоровые люди, не имевшие заработка. В практике применения трудовых норм одним из самых суровых законов стал закон от 1 августа 1926 г., по которому запрещалось работать по найму без разрешения властей. Для рабочих-иностранцев вводилась $20 \%$-ная норма (четыре француза - один иностранец). В 1932 г. во Франции вышел другой закон о $10 \%$-ной норме иностранцев в отношении права на труд. Непреложность этого закона французский делегат оговорил при подписании Конвенции 1933 г. Тем самым закон ограждал национальный труд от конкуренции иностранцев. Рабочая сила в промышленности Франции распределялась крайне неравномерно. Отрасли, наиболее привлекательные для российских беженцев, 170 
были обеспечены собственными кадрами. Для некоторых видов труда требовался ценз оседлости. Так, устроиться шофером такси можно было только после пятилетнего пребывания в стране или при наличии родившегося во Франции ребенка $[5$, с. 30]. Почти невозможен был переход из сельскохозяйственных отраслей в промышленность. После 1935 г. торговлю вразнос запретили тем иностранцам, которые прожили в стране менее пяти лет. Нарушение этого правила, писали «Последние новости» 3 ноября 1935 г., вело к штрафу от 5 до 15 франков или к аресту сроком от одного до пяти дней.

Карт д’идантите рабочей категории не выдавалась без рабочей карточки. Рабочую карточку нельзя было получить без «благоприятного отзыва» Министерства труда. В Министерстве труда следовало получить разрешение на трудоустройство в определенной области. Иностранцы, прибывшие во Францию по контрактам, заключенным за границей, пользовались правом на рабочую карт д’идантите. Если иностранец прибывал без контракта, но желал устроиться на работу, он должен был в течение восьми дней обратиться в префектуру (мэрию, комиссариат), подать прошение о карт д’идантите «без профессии», уплатив 100 франков. Найдя работодателя, он получал от него рабочий сертификат (или контракт) с указанием о согласии принять на службу данное лицо, если оно получит разрешение от Министерства труда. Рабочего должны были принять на срок не менее года. Контракт заверялся у комиссара полиции по месту жительства. Министерство труда назначало медицинское освидетельствование (за 30 франков), после чего выдавало avis fovorabl («благоприятный отзыв») разрешение на работу. Затем можно было получать рессеписе или новую карт д'идантите. Предприниматель, принявший на работу иностранца, не имевшего рабочей карты, или получившего неблагоприятный отзыв Министерства труда, мог быть оштрафован на 5001000 франков. Иностранный рабочий в таком случае рисковал никогда не получить разрешение на работу и даже быть высланным из Франции. Иностранцы, прожившие во Франции более пяти лет, освобождались от необходимости получения avis fovorabl. Этот порядок кратковременно был отменен в 1930 г., но восстановлен с января 1931 г. Иностранцы, прибывшие в страну после 1 января 1930 г. без рабочих контрактов, заключенных за границей, получить avis fovorabl не могли (по соглашению министерств иностранных дел и труда) $[16$, c. $81-85]$. К этому времени такие контракты Францией практически не выдавались. Для возобновления рабочей карты потерявший работу беженец должен был вновь обратиться в Министерство труда, представив карт д’идантите, паспорт, с которым прибыл во Францию, доказательства пребывания во Франции и рабочее свидетельство в двух экземплярах (см.: «Последние новости» от 17 ноября 1935 г.).

Закон 8 августа 1935 г. установил особую карту артизана (ремесленника) и строгую регламентацию ее выдачи. Ремесленники были приравнены 
к рабочим. Ремесленники-иностранцы отныне были не вправе заниматься своей профессией, если не имели специальной карты д'идантите ремесленника. Они выдавались на основе прошения и анкеты в комиссариате полиции или в мэрии. Выдавала такую карту комиссия при Министерстве труда. Однако на практике в работе отказывали. «Последние новости» от 3 декабря 1938 г. сообщали об одном русском парикмахере в Париже, в карт д'идантите которого значилось: «парикмахер за свой счет». Когда срок карты истек, в префектуре потребовали выбрать карту артизана (ремесленника), а Министерство труда в этом отказало. Далее поступило предписание властей немедленно закрыть салон, иначе владельцу грозил штраф и высылка.

Безработица обрекала на нищенское, полуголодное существование. Именно такое свидетельство находим в архиве Королевского музея армии и военной истории Бельгии, фонда Объединения бывших воспитанников императорского Александровского лицея, XV C(1)-1. В 1938 г. бывший лицеист Б.В. Балашев, проживавший с 1923 г. в Ницце писал председателю этого Объединения В.Н. Коковцову: «Не имея постоянной работы вот уже несколько лет, я нахожусь в более чем стесненном материальном положении. С момента увеличения платы за carte d'identité я уже не имел возможности еe возобновлять, ввиду чего на меня нарос штраф за 11 лет. В настоящее время при новом суровом законе об иностранцах дальше оставаться без документов было невозможно, и я начал хлопотать по этому делу. Выяснилось, что мне придется заплатить штраф, хотя и в уменьшенном размере, но все-таки это выразится в сумме не менее 500 франков. Достать эти деньги я совершенно не могу, так как при моих заработках веду полуголодную жизнь». Заметим, что в 1938 г. штраф с рабочих карт составлял 20 франков в месяц, с нерабочих - 100. Казначей Объединения Ф. Кичч 24 июля 1938 г. в письме В.Н. Коковцову подтвердил тяжелое положение Б.В. Балашева и свидетельствовал, что однокашники собрали для него деньги, на которые удалось получить временное свидетельство о личности, рессеписе, но далеко не полную сумму (500 франков - штраф и нансеновский сбор). (Префектура (мэрия или комиссариат в провинции) сначала выдавала иностранцу рессеписе, которое через три месяца обменивалось на карт д’идантите.) Дополнительно Ф. Кичч разъяснял, что рабочую карту получить Б.В. Балашеву не удалось, ибо этот процесс был длительным, решавшимся в нескольких инстанциях. Ниццский префект не снял с Балашева штрафа, но уменьшил его сумму.

Когда «сидение на чемоданах» затянулось, чтобы не оказаться на дне жизни, обеспечить возможность социального лифта, если не себе, то детям, эмигранты стали задумываться о переходе во французское гражданство. Натурализация во Франции до 1927 г. была многоступенчатой и длительной. После принятия нового закона иностранцы, в том числе нансенисты, могли подать прошение, прожив беспрерывно во Франции уже не десять, а всего 
три года [1, с. 112]. Прошение заполнялось на гербовой бумаге (3 франка 60 сантимов) на имя министра юстиции, подавалось префекту департамента лично. Если иностранцу было менее 21 года, прошение должно было быть подписано не только им, но и его отцом или опекуном, или прилагалось письменное согласие семейного совета. Для натурализации требовались также национальный паспорт (или нансеновский), с которым прибыл ходатайствующий, доказательства трехлетнего пребывания во Франции (сертификат де домисиль, заверенный комиссаром, квитанции об уплате квартирной платы), квитанции об уплате налогов, документ об отбытии воинской повинности, карт д'идантите, метрическое свидетельство о рождении или выданный мировым судьей документ, его заменявший, рабочее свидетельство, заверенное комиссаром полиции. Российские эмигранты должны были представить еще свидетельство о национальности, выданное организацией беженцев [16, c. 92-93]. Перевод документов на французский язык должен был сделать присяжный переводчик. Процесс натурализации занимал примерно один год. Льготы предоставлялись мужчинам, женатым на француженках, для которых ценз оседлости сокращался до одного года со дня прибытия во Францию, а также лицам, окончившим высшие учебные заведения во Франции, либо оказавшим стране особые услуги. У безработных шансов на положительное решение не было.

Следующий этап начался в 1938 г., когда 12 ноября во Франции вышли новые правила натурализации. Закон устанавливал для иностранцев различия между понятиями «résidence» (временное проживание) и «domicile» (постоянное проживание). Длительность пребывания во Франции играла большую роль при натурализации. Отныне каждый иностранец, возбуждавший ходатайство о натурализации, должен был сам предоставлять доказательства того, что его «résidence» или «domicile» во Франции соответствует требованиям закона. Мировым судьей производилось дознание с целью установления моральных качеств кандидата, его лояльности при условии, что лицу, возбудившему ходатайство, более 15 лет. До сих пор иностранка, выходившая замуж во Франции за француза, автоматически приобретала права французской гражданки. Теперь же автоматически она гражданства не приобретала, но имела право об этом ходатайствовать. Для этого иностранка заполняла специальный формуляр, который передавался далее в Министерство юстиции, а власти уже производили дознание с целью выяснения моральных качеств и лояльности кандидата и могли отказать. Француженка, выходившая замуж за иностранца на французской территории, сохраняла свое гражданство (см.: «Последние новости». Париж, 1938. 14 декабря).

С 1926 по 1936 г. число натурализовавшихся русских возросло более чем в 2 раза, т.е. с $8 \%$ - в 1926 г., 13 - в 1931 г. до почти $18 \%$ - в 1936 г. от общего числа российских эмигрантов в стране. В декабре 1938 г. префект Сены Виллэ 
говорил, что 99\% сыновей иностранцев, родившихся во Франции и тем самым имевших право выбора гражданства в момент достижения ими совершеннолетия, желали остаться французами, отбывали воинскую повинность [2, c. 141].

Депутат французского парламента М. Рюкар во время беседы с корреспондентом «Последних новостей» (9 августа 1936 г.) говорил, что число подавших прошение о натурализации с каждым годом возрастало, особенно после ограничений для иностранного труда в 1926 и 1932 гг. К середине 1930-х годов число лиц, желавших натурализоваться, доходило до 100 тыс. в год. Персонал бюро по натурализации не справлялся с таким потоком. Он же отмечал, что беспрепятственно во французское гражданство принимали отцов семейств, а $50 \%$ молодых людей, признанных годными к военной службе, - дети натурализованных. Причем ходатайства, поданные женщинами, как правило, не удовлетворялись, ибо женщины, желавшие стать француженками, могли легко это сделать, выйдя замуж за француза. Ходатайства мужчин-холостяков, особенно старше определенного возраста, допускаемого для отбывания воинской повинности, как правило, не удовлетворялись. Поощрялась натурализация здоровых и достойных элементов. Исключение было сделано для иностранцев, сражавшихся за Францию; родителей французских детей; лиц, женатых на француженках. Правда, главную массу натурализованных составляли не русские, а рабочие Бельгии и Италии, которым охотно предоставляли это право, и в виде исключения - поляки (на севере).

В 1931 г. во Франции насчитывалось 82908 русских, обладателей нансеновских паспортов, и 10980 человек бывших русских, получивших французское подданство. В 1936 г. их было уже 77767 и 13810 соответственно. В Париже в 1937 г., по официальной статистике, проживали 32915 русских беженцев, не имевших французского гражданства, еще 1582 имели советские паспорта [8, с. 32].

Опыт российского зарубежья 1920-1930-х годов по установлению сбалансированных отношений между диаспорами, властями и международными организациями, а также анализ форм и способов самоорганизации остается актуальным и по сей день, хотя эмигрантам и удалось блокировать агрессивную среду, связанную с суровыми условиями конкуренции на трудовом рынке, закрытостью местной системы здравоохранения, ограничениями в получении образования и т.д., но лишь в незначительной степени. Современное французское законодательство в отношении предоставления убежища восприняло многое из опыта 1920-1930-х годов. Выведенная на мировой уровень русская беженская проблема, стала универсальной, постоянной и одной из самых острых в международных отношениях и на национальном уровне. Но при этом ее основное содержание - людские страдания - затерялось в политических схватках держав и их военных конфликтах. 


\section{Библиография}

1. Бойко Ю.В. О влиянии смешанных браков на процессы социальной адаптации россиян во Франции 1920-х годов // История российского зарубежья. Проблемы адаптации мигрантов в ХІХ-ХХ веках. М.: ИРИ РАН, 1996. С. 105-114.

2. Бойко Ю.В. Переписи населения Франции как источник по истории социальной адаптации российских эмигрантов // Источники по истории адаптации российских эмигрантов в ХІХ-ХХ вв. М.: ИРИ РАН, 1997. С. 135-147.

3. Бочарова 3.С. Нансеновский паспорт: История создания и практика применения // Нансен. Человек и миф. Международная конференция. Москва - 26 октября 2011 года. М., 2011. С. 74-116.

4. Бюллетень Российского земско-городского комитета помощи российским гражданам за границей. 15 января 1930 г. Париж: Земгор, 1930. № 56.

5. Бюллетень Российского земско-городского комитета помощи российским гражданам за границей. 15 марта 1930 г. Париж: Земгор, 1930. № 57-58.

6. Ипполитов С.С., Недбаевский В.М., Руденцова Ю.И. Три столицы изгнания: Константинополь. Берлин. Париж. М.: Спас, 1999. 206 с.

7. Кельман Е.И. Советское право за рубежом. М.: Юрид. изд-во НКЮ РСФСР, 1927. $95 \mathrm{c}$.

8. Ковалевский П.Е. Зарубежная Россия. История и культурно-просветительная работа русского зарубежья за полвека (1920-1970). Париж: Librarie des Cinq Continents, 1971. 347 с.

9. Кодрянская Н.В. Алексей Ремизов. Париж: б/и, 1959. 329 с.

10. Маклаков В.А. Новые элементы в улучшении положения русских беженцев во Франции // Закон и суд. Рига, 1930. № 10. Ст. 336-340.

11. «Наши жалобы - глас вопиющего в пустыне». Судьба русских солдат французского иностранного легиона. 1920-1925 гг. / Сост. 3.С. Бочарова // Исторический архив. 2011. № 2. C. $131-147$.

12. Письмо Союза русских адвокатов во Франции к министру юстиции // Закон и суд. Рига, 1935. № 1 (51). Ст. 1833.

13. Постановление о правовом положении русских и армянских беженцев // Закон и суд. Рига, 1930. № 8. Приложение к № 8 .

14. Протоколы заграничных групп конституционно-демократической партии. 19231933 гг. Т. 6. Кн. 2. М.: РОССПЭН, 1999. 559 с.

15. Русские во Франции. Справочник / Под ред. В.Ф. Зеелера. Париж: Сарач, 1937. 86 с.

16. Русский альманах: Справочник / Под ред. В.А. Оболенского и Б.М. Сарача. Париж: Сарач, 1931. 464 c.

17. Саша Черный. Начало сезона // Собр. соч.: В 5 т. Т. 3. Сумбур-трава. Впервые опубликовано: Иллюстрированная Россия. 1925. № 28. URL: http://ruslit.traumlibrary.net/book/ cherniy-ss05-03/cherniy-ss05-03.html\#c004017 (Дата обращения: 10.02.2017.)

18. Седых А. Далекие, близкие. М.: Новое Русское Слово, 1995. 268 с.

19. Справка о положении русских беженцев в Константинополе, подготовленная представителем Всероссийского земского союза в Константинополе А.Л. Глазовым для М.Н. Гирса, 2 апреля 1926 г. // Новый исторический вестник. 2002. № 2 (7). С. 231-233.

20. Уляницкий В. Международное право. Томск: П.И. Макушин, 1911. 482 с.

21. Шефтель Я.М. К вопросу о юридическом статусе русских беженцев во Франции // Право и хозяйство. Париж, 1925. № 3. С. 8-9. 


\section{References}

Bojko Ju.V. O vlijanii smeshannyh brakov na processy social'noj adaptacii rossijan vo Francii 1920-h godov // Istorija rossijskogo zarubezh'ja. Problemy adaptacii migrantov v XIX-XX vekah. Moscow: IRI RAN, 1996. P. 105-114.

Bojko Ju.V. Perepisi naselenija Francii kak istochnik po istorii social'noj adaptacii rossijskih jemigrantov // Istochniki po istorii adaptacii rossijskih jemigrantov v XIX-XX vv. Moscow: IRI RAN, 1997. P. 135-147.

Bocharova Z.S. Nansenovskij pasport: Istorija sozdanija i praktika primenenija // Nansen. Chelovek i mif. Mezhdunarodnaja konferencija. Moskva - 26 oktjabrja 2011 goda. Moscow, 2011. P. 74-116.

Bjulleten' Rossijskogo zemsko-gorodskogo komiteta pomoshhi rossijskim grazhdanam za granicej. 15 janvarja 1930 g. Parizh: Zemgor, 1930. N 56.

Bjulleten' Rossijskogo zemsko-gorodskogo komiteta pomoshhi rossijskim grazhdanam za granicej. 15 marta 1930 g. Parizh: Zemgor, 1930. N 57-58.

Ippolitov S.S., Nedbaevskij V.M., Rudencova Ju.I. Tri stolicy izgnanija: Konstantinopol'. Berlin. Parizh. Moscow: Spas, 1999. 206 p.

Kel'man E.I. Sovetskoe pravo za rubezhom. Moscow: Jurid. izd-vo NKJu RSFSR, 1927. 95 p.

Kovalevskij P.E. Zarubezhnaja Rossija. Istorija i kul'turno-prosvetitel'naja rabota russkogo zarubezh'ja za polveka (1920-1970). Parizh: Librarie des Cinq Continents, 1971. 347 p.

Kodrjanskaja N.V. Aleksej Remizov. Parizh: b/i, 1959. 329 p.

Maklakov V.A. Novye jelementy v uluchshenii polozhenija russkih bezhencev vo Francii // Zakon i sud. Riga, 1930. N 10. St. 336-340.

«Nashi zhaloby - glas vopijushhego v pustyne». Sud'ba russkih soldat francuzskogo inostrannogo legiona. 1920-1925 gg. / Sost. Z.S. Bocharova // Istoricheskij arhiv. 2011. N 2. P. 131-147.

Pis'mo Sojuza russkih advokatov vo Francii k ministru justicii // Zakon i sud. Riga, 1935. N 1 (51). St. 1833.

Postanovlenie o pravovom polozhenii russkih i armjanskih bezhencev // Zakon i sud. Riga, 1930. N 8. Prilozhenie k N 8.

Protokoly zagranichnyh grupp konstitucionno-demokraticheskoj partii. $1923-1933$ gg. T. 6 .

Kn. 2. Moscow: ROSSPEN, 1999. 559 p.

Russkie vo Francii. Spravochnik / Pod red. V.F. Zeelera. Parizh: Sarach, 1937. 86 p.

Russkij al'manah: Spravochnik / Pod red. V.A. Obolenskogo i B.M. Saracha. Parizh: Sarach, 1931. 464 p.

Sasha Chernyj. Nachalo sezona // Sobr. soch. v pjati tomah. T. 3. Sumbur-trava. Vpervye opublikovano: Illjustrirovannaja Rossija. 1925. N 28. URL: http://ruslit.traumlibrary.net/book/cherniyss05-03/cherniy-ss05-03.html\#c004017 (Data obrashhenija: 10.02.2017.)

Sedyh A. Dalekie, blizkie. Moscow: Novoe Russkoe Slovo, 1995. 268 p.

Spravka o polozhenii russkih bezhencev v Konstantinopole, podgotovlennaja predstavitelem Vserossijskogo zemskogo sojuza v Konstantinopole A.L. Glazovym dlja M.N. Girsa, 2 aprelja 1926 g. // Novyj istoricheskij vestnik. 2002. N 2 (7). P. 231-233.

Uljanickij V. Mezhdunarodnoe pravo. Tomsk: P.I. Makushin, 1911. 482 p.

Sheftel' Ja.M. K voprosu o juridicheskom statuse russkih bezhencev vo Francii // Pravo i hozjajstvo. Parizh, 1925. N 3. P. 8-9. 